\title{
LEMBAGA PENDIDIKAN ISLAM TERPADU
}

\author{
Mualimin \\ Mualimin@gmail.com \\ Universitas Negeri Lampung
}

\begin{abstract}
Education in Indonesia only recognizes three models of educational institutions namely Islamic boarding schools, madrasas, and schools (general). The purpose of this article is to explain the phenomenon of the birth and development of the Integrated Islamic School in Indonesia, the philosophy and ideology of the education of the Integrated Islamic School that distinguishes from existing educational institutions, to the impact caused by the development of these schools. The results of this study can explain why the development of the Integrated Islamic School was so rapid and the response of the community was enthusiastic. The Integrated Islamic School in its application is a school that implements an implementation approach by integrating general education and religious education into a curriculum. The Integrated Islamic School also emphasizes integration in learning methods so that it can optimize the cognitive, affective, and conative domains. The Integrated Islamic School also combines aqliyah, ruhiyah, and jasadiyah education. In its implementation, it combines the involvement and active participation of the learning environment, namely school, home and community.
\end{abstract}

Keywords: Integrated Islamic Institutions and Education.

\begin{abstract}
Abstrak
Pendidikan di Indonesia hanya mengenal tiga model lembaga pendidikan yakni pesantren, madrasah, dan sekolah (umum). Adapun tujuan penulisan artikel ini untuk menjelaskan fenomena lahir dan berkembangnya Sekolah Islam Terpadu di Indonesia, filsafat dan ideologi pendidikan Sekolah Islam Terpadu yang membedakan dengan lembaga-lembaga pendidikan yang telah ada sebelumnya, hingga dampak yang ditimbulkan oleh perkembangan sekolah-sekolah ini. Hasil penelitian ini dapat menjelaskan mengapa perkembangan Sekolah Islam Terpadu demikian pesat dan respons masyarakat demikian antusias. Sekolah Islam Terpadu dalam aplikasinya merupakan sekolah yang menerapkan pendekatan penyelenggaraan dengan memadukan pendidikan umum dan pendidikan agama menjadi suatu jalinan kurikulum. Sekolah Islam Terpadu juga menekankan keterpaduan dalam metode pembelajaran sehingga dapat mengoptilmalkan ranah kognitif, afektif, dan konatif. Sekolah Islam Terpadu juga memadukan pendidikan aqliyah, ruhiyah, dan jasadiyah. Dalam penyelenggaraannya memadukan keterlibatan dan partisipasi aktif lingkungan belajar yaitu sekolah, rumah, dan masyarakat.
\end{abstract}

Kata Kunci: Lembaga dan Pendidikan Islam Terpadu. 


\section{PENDAHULUAN}

Menjelang abad ke 21, model lembaga pendidikan di Indonesia hanya mengenal tiga model lembaga pendidikan yakni pesantren, madrasah, dan sekolah (umum) (Azhari \& Saleh, 1989). Pesantren merupakan lembaga pendidikan Islam tradisional dengan ciri khas di dalamnya terdapat masjid, kyai, santri, dan pengajaran kitab kuning (Abdalla, 2006; Hayati, 2011). Tujuan pendidikan di pesantren adalah untuk menghasilkan para ahli ilmu agama (Steenbrink, 1986).

Di lembaga inilah kaum muslimin Indonesia mengalami doktrin dasar Islam, khususnya menyangkut praktek kehidupan dan keagamaan. Ciri umum yang diketahui adalah pesantren memiliki kultur yang khas. Cara pengajarannya yang unik. Kyai yang biasanya adalah pendiri pondok pesantren, memberikan layanan pendidikan secara kolektif atau bandongan ( collective learning process) dan layanan individual atau sorogan (individual learning process) (Sulhan, 2015).

Madrasah merupakan tempat pendidikan yang memberikan pendidikan dan pengajaran agama maupun umum, yang berada di bawah naungan Kementerian Agama RI (Zuhdi, 2012). Lembaga madrasah tidak dapat digantikan dengan lembaga-lembaga lainnya, karena madrasah mempunyai visi, misi dan karakteristik yang sangat spesifik di dalam masyarakat maupun kelembagaannya baik (Fitri \& Hatta, 2013). Lebih dari 20 tahun terakhir, banyak pesantren telah mengadopsi sistem madrasah dan memasukkan mata pelajaran umum dalam sistem pendidikannya. Sistem madrasah diperkenalkan untuk menjembatani kesenjangan antara pesantren dan sekolah yang pada akhirnya melahirkan dualisme dalam sistem pendidikan nasional. Sekolah (umum) merupakan lembaga pendidikan di Indonesia warisan penjajah Belanda yang mengajarkan ilmuilmu umum yaitu ilmu alam, ilmu sosial, dan humaniora.

Islam menjelaskan bahwa Allah SWT menciptakan manusia berasal dari tanah, kemudian menjadi nutfah, alaqah, dan mudgah sehingga akhirnya menjadi makhluk Allah SWT yang paling sempurna dan memiliki berbagai kemampuan. Allah SWT sudah menciptakan manusia ahsanu taqwim, yaitu sebaik-baik cipta dan menundukkan alam beserta isinya bagi manusia agar manusia dapat memelihara dan mengelola serta melestarikan kelangsungan hidup di alam semesta ini (Sada, 2016).

Lembaga pendidikan Islam juga dapat dikategorikan sebagai lembaga industri mulia (noble industry) kerena mengemban misi ganda profit sekaligus sosial. Misi 
profit, yaitu untuk mencapai keuntungan, ini dapat dicapai ketika efisiensi dan efektifitas dana bisa tercapai, sehingga pemasukan (income) labih besar dari biaya operasional. Sedangkan misi sosial bertujuan untuk mewariskan dan menginternalisasikan nilai luhur (Muhaimin, Suti'ah, \& L.P, 2009; Rifa'i, 2012).

Peran lembaga pendidikan Islam adalah pelaksana operasional dalam menjalankan fungsi pendidikan Islam. Dengan demikian misi lembaga pendidikan Islam harus sejalan dengan misi pendidikan Islam yakni membentuk manusia beradab yaitu manusia yang sadar atas hak dan kewajiban atas Tuhannya, atas dirinya dan atas lingkungannya (Khadijah, 2015).

Sekolah Islam Terpadu menekankan pada penanaman mata pelajaran keagamaan seperti teologi (akidah), moral (akhlaq), dan ibadah praktis bertujuan untuk membangun karakter dan moralitas siswa dengan warna Islam yang direfleksikan dalam cara berpikir, sikap, dan praktik kehidupan sehari-hari(Kurnaengsih, 2015).

Pada dekade akhir tahun 1980-an, Sekolah Islam Terpadu mulai bermunculan dengan diawali oleh para aktivis dakwah kampus yang tergabung dalam Lembaga Dakwah Kampus (LDK) Institut Teknologi Bandung (ITB), Universitas Indonesia (UI), dan beberapa universitas ternama lainnya yang tergabung dalam komunitas Jamaah Tarbiyah yang memiliki keprihatinan terhadap kondisi pendidikan di Indonesia. Mereka adalah para aktivis Islam kampus yang berperan penting dalam menyebarkan ideologi Islam kepada para mahasiswa. Kalangan pemuda menjadi target utama dari gerakan ini karena mereka percaya bahwa para pemuda akan menjadi agen perubahan sosial yang sangat penting dalam melakukan Islamisasi seluruh masyarakat Indonesia (Frimayanti, 2015; Qodir, 2009). Tugas untuk menyiapkan generasi muda Muslim yang punya komitmen dakwah diyakini akan lebih efisien jika melalui pendidikan. Mereka mendirikan Sekolah Islam Terpadu (SIT) Nurul Fikri dari tingkat Taman Kanak-kanak (TK) hingga Sekolah Menengah Atas (SMA) yang telah menginspirasi berdirinya Sekolah-Sekolah Islam Terpadu di seluruh wilayah Indonesia. Ada sekitar 1.000 Sekolah Islam Terpadu yang tergabung dalam Jaringan Sekolah Islam Terpadu (JSIT) yang kepengurusannya telah tersebar diseluruh wilayah Indonesia, dan ada sekitar 10.000 Sekolah IslamTerpadu yang secara struktural tidak bergabung di bawah JSIT (Hisyam, 2012). 
Data di atas menunjukkan bahwa perkembangan Sekolah Islam Terpadu mendapat sambutan yang demikian antusias dari masyarakat luas. Sambutan masyarakat yang demikian luas ini disebabkan karena ada ketidakpuasan sebagian besar masyarakat Indonesia terhadap lembaga pendidikan yang telah eksis sebelumnya yang meliputi pesantren, madrasah, dan sekolah (umum). Masyarakat menghendaki adanya sebuah lembaga pendidikan yang dapat memberikan bekal yang memadai bagi anak didik untuk menghadapi tantangan perkembangan zaman yang demikian dahsyat. Oleh karena itu, dibutuhkan sebuah lembaga pendidikan yang memadukan antara pendidikan modern sehingga anak tetap mampu merespons perkembangan dunia modern, namun juga memiliki basic keagamaan yang kuat sebagai landasan pembentukan moral.

Wacana pemaduan sains dan Islam meningkat seiring sejalan dengan tumbuh suburnya ideologi Islam yang sangat asertif dalam mencoba mengimplementasikan berbagai visi-visi Islam dalam pendidikan, sosial, ekonomi, maupun politik. Hal ini tidaklah mengherankan karena para pendiri Sekolah-sekolah Islam Terpadu secara umum memiliki semangat yang tinggi untuk meniru dan mengulangi kembali "zaman keemasan Islam" yang dianggap lebih murni, Islam ideal yang mana kehidupan zaman sekarang harus didasarkan (Kurnaengsih, 2015).

Tujuan kajian ini yaitu untuk menjelaskan fenomena lahir dan berkembangnya Sekolah Islam Terpadu di Indonesia, filsafat dan ideologi pendidikan Sekolah Islam Terpadu yang membedakan dengan lembaga-lembaga pendidikan yang telah ada sebelumnya, hingga dampak yang ditimbulkan oleh perkembangan sekolah-sekolah ini.

\section{HASIL KAJIAN DAN PEMBAHASAN}

\section{A. Sejarah Sosial Munculnya Pendidikan Islam Terpadu}

Islam telah mempunyai tradisi dikotomi ini lebih dari seribu tahun silam. Tetapi dikotomi tersebut tidak menimbulkan terlalu banyak problem dalam sistem pendidikan Islam, sehingga sistem pendidikan sekuler Barat diperkenalkan ke dunia Islam melalui imperialisme. Hal ini terjadi karena sekalipundikotomi antara ilmu-ilmu agama dan ilmu non-agama telah dikenal dalam karya karya klasik seperti yang ditulis oleh alGhazali dan Ibnu Khaldun, mereka tidak mengingkari tetapi mengakui validitas dan status ilmiah masing-masing kelompok keilmuan tersebut (Kartanegara, 2005).

Berbeda dengan dikotomi yang dikenal oleh dunia Islam, sains modern Barat sering menganggap rendah status keilmuan ilmu-ilmu agama. Ketika berbicara tentang 
ilmu-ilmu goib, ilmu agama tidak bisa dipandang ilmiah karena sebuah ilmu bisa dipandang ilmiah apabila objek-objeknya bersifat empiris. Padahal ilmu-ilmu agama tentunya tidak bisa menghindar dari membicarakan hal-hal yang ghaib.

Ketika ilmu-ilmu sekuler positivistik tersebut diperkenalkan ke dunia Islam melalui imperialisme Barat, terjadilah dikotomi yang sangat ketat antara ilmu-ilmu agama, sebagaimana yang dipertahankan dan dikembangkan oleh lembaga-lembaga pendidikan Islam tradisional (pesantren) di satu pihak dan ilmu ilmu sekuler sebagaimana diajarkan di sekolah-sekolah umum yang disponsori oleh pemerintah di pihak lain. Dikotomi ini menjadi sangat tajam karena telah terjadi pengingkaran terhadap validitas dan status ilmiah yang satu atas yang lain. Pihak kaum tradisional menganggap bahwa ilmu-ilmu umum itu bid'ah dan haram dipelajari karena berasal dari orang-orang kafir sementara pendukung ilmu-ilmu umum menganggap ilmu-ilmu umum sebagai pseudo ilmiah atau hanya sebagai mitologi yang tidak akan sampai pada tingkat ilmiah karena tidak berbicara tentang fakta tetapi tentang makna yang tidak bersifat empiris. Pada saat ini justru dikotomi seperti inilah yang terjadi dan telah menimbulkan berbagai problem yang akut dalam sistem pendidikan Islam.

Hal tersebut dapat dibuktikan dengan adanya dua model lembaga pendidikan formal di Indonesia. Model yang pertama adalah sekolah-sekolah yang dikenal dengan sekolah umum seperti SD, SMP, dan SMU. Model yang kedua yaitu sekolah-sekolah yang dikenal dengan sekolah agama seperti MI, MTs dan MA. Model yang kedua inilah yang dalam sistem pendidikan nasional merupakan wujud dari lembaga pendidikan Islam. Di sekolah agama memiliki komposisi kurikulum 30 persen mata pelajaran agama sedangkan selebihnya 70 persen mata pelajaran umum (Fathoni, 2005).

Presentase tersebut membuktikan adanya pemisahan secara substansial antara mata pelajaran agama dan mata pelajaran umum. Akibatnya banyak mata pelajaran yang pada hakekatnya mempelajari ayat-ayat Tuhan akan tetapi sama sekali terputus dengan kebesaran Tuhan. Sebagai contoh, mata pelajaran Sains yang notabenenya adalah membicarakan tentang alam, dengan kata lain membicarakan tentangayat-ayat kauniyah Tuhan, tetapi pelajaran tersebut jarang sekali memperkenalkankebesaran Tuhan.

Pendidikan Islam tidak mengenal adanya dikotomi antara ilmu pengetahuan umum dan ilmu agama karena keduanya sama-sama sebagai ayat Tuhan. Syafi'i Ma'arif dalam (Wijaya, 1987) mengatakan Pendidikan Islam sekarang menganut sistem 
pendidikan warisan abad pertengahan bagian akhir. Ciri utama dari warisan tersebut adalah adanya pemisahan secara jelas antara ilmu pengetahuan yang terklasifikasikan (agama dan umum), sedangkan kedudukan pendidikan Islam sebagai sub sistem pendidikan nasional merupakan sisi lain yang bersumber dari sistem penyelenggaraan negara yang sesungguhnya juga sebagai bentuk modifikasiyang tidak sempurna atas warisan sejarah masa lalu tentang pendidikan modern yang kita anut. Sebagai akibatnya gejala ini sedikit banyak telah mempengaruhi kemajuan pendidikan khususnya pendidikan Islam.

Kondisi seperti ini tentunya menyebabkan pendidikan Islam mengalami kerugian karena yang dihasilkan oleh model-model sekolah tersebut adalah manusia yang tertinggal oleh kemajuan IPTEK di satu sisi dan di sisi lain juga tertinggal dalam pengetahuan agama. Tertinggal dalam bidang IPTEK dikarenakan tidak seluruhwaktu dan potensinya digunakan untuk mempelajari IPTEK akibat kurikulum yang harus dijalani. Tertinggal dalam bidang agama dikarenakan kurikulum yangada hanya terdapat sedikit pelajaran agama, itupun materinya sudah terjauhkan dari nilai-nilai tauhid. Hal itu menyebabkan usaha untuk mengubah atau membentuk sosok pribadi muslim sesuai yang diidamkan oleh pendidikan Islam sangat kecil.

Oleh karena itu dibutuhkan lembaga pendidikan Islam alternatif yang mampu menghapus dikotomi ilmu pengetahuan.Wacana integrasi, sebenarnya sudah berkembang pada abad-abad terdahulu, sebagaimana telah banyak dikemukakan oleh ilmuwan-ilmuwan di dunia Muslim. Meskipun demikian, wacana tersebut sampai saat ini secara resmi masih jarang menjadi karaktersitik dari sebuah lembaga pendidikan.

\section{B. Reintegrasi Keilmuan Pendidikan Islam}

Sekolah Islam Terpadu merupakan pendatang baru dalam kancah pendidikan di Indonesia sehingga mereka memiliki pilihan yang fleksibel terhadap kurikulum yang diterapkan. Meskipun demikian, ada pertimbangan-pertimbangan tertentu yang dipakai ketika memilih kurikulum yang akan diterapkan. Pertimbangan tersebut sebagai contoh adalah pertimbangan pragmatis. Karena berada di wilayah Negara Kesatuan Republik Indonesia (NKRI) maka mereka harus memilih antara kurikulum Kementerian Pendidikan dan Kebudayaan dengan kurikulum Kementerian Agama. Pertimbangan ini dilakukan dalam rangka untuk memberikan nilai plus kepada para pengguna lembaga pendidikan tersebut. 
Secara administratif pendidikan Islam Terpadu berada di bawah Kementerian Pendidikan danKebudayaan di karena menggunakan nama SD, SMP, dan SMU. Berbagai alasan mengapa para pendiri Sekolah Islam terpadu (IT) memilih menggunakan nama SD, SMP, dan SMU. Karena di mata masyarakat, nama SD, SMP, dan SMU lebih banyak menjadi pilihan dibandingkan dengan nama lain, madrasah misalnya. Karena menggunakan nama tersebut, maka model kurikulum yang digunakan cara modifikasi mata pelajaran umum yang disisipkan mata pelajaran keagamaan.

Kurikulum yang diterapkan oleh Sekolah Islam Terpadu pada dasarnya adalah kurikulum yang diadopsi dari kurikulum Kementerian Pendidikan dan Kebudayaan dengan berbagai modifikasi di sana-sini. Jika melihat struktur kurikulumnya, Sekolah Islam Terpadu merupakan bagian integral dari sistem pendidikan nasional. Sekolah Islam Terpadu menerima seluruhnya mata pelajaran dari kurikulum nasional. Kurikulum yang disusun oleh Badan Standar Nasional Pendidikan (BSNP) yang kemudian dijadikan sebagai Peraturan Menteri Pendidikan dan Kebudayaan No. 22 tahun 2006, terdapat 8 mata pelajaran untuk siswa Sekolah Dasar ditambah dengan muatan lokal dan pengembangan diri, 10 mata pelajaran untuk Sekolah Menengah Pertama/ Madrasah Tsanawiyah ditambahmuatan lokal dan pengembangan diri, 15 mata pelajaran untuk Sekolah Menengah Umum/Madrasah Aliyah ditambah dengan muatan lokal dan pengembangan diri.

Sekolah Islam Terpadu tidak menolak mata pelajaran Matematika, Ilmu Pengetahuan Alam, Ilmu Pengetahuan Sosial, Bahasa dan Seni, yang merupakan format baku dari kurikulum pendidikan nasional. Sekolah Islam Terpadu menganggap bahwa dengan memberikan mata pelajaran-mata pelajaran umum maka dapat menjadi alat untuk membekali para lulusan dalam mengembangkan profesi masa depan anak didik baik sebagai seorang insinyur, ekonom, dokter, psikolog, dan profesi-profesi dibidang lain. Perpaduan antara mata pelajaran umum dan mata pelajaran keagamaan menjadi ciri khas dalam struktur kurikulum Sekolah Islam Terpadu. Sekolah IslamTerpadu tidak memisahkan keduanya menjadi mata pelajaran keagamaan yang fardhu'ain untuk dipelajari dan ilmu umum yang fardhu kifayah untuk dipelajari, namun kedua-keduanya merupakan rumpun keilmuan yang wajib dipelajari sebagai bekal menjalankan tugas manusia sebagai kholifah Allah di muka bumi. Kedua rumpun keilmuan tersebut dianggap sama-sama mempelajari ayat-ayat Allah SWT. Satu rumpun keilmuan 
mempelajari ayat-ayat Allah yang tertulis dalam teks al-Qur'an dan Hadis, rumpun keilmuan yang lain mempelajari ayat-ayat Allah berupa alam semesta.Keduanya tidak mungkin bertentangan karena sama-sama berasal dari Allah SWT. Hal ini sesuai dengan pemikiran para filosof Muslim yang menyatakan bahwa "The words of God can not possibly contradict the work of God." Kata kata Tuhan (al-Qur'an dan al-Hadis) tidak mungkin bertentangan dengan karya Tuhan (alam semesta).

Kurikulum sebagaimana di atas, jika dilihat dari perspektif epistmologi pendidikan Islam, sebenarnya berasal dari pandangan adanya integrasi ilmu antara ilmu agama dan ilmu umum. Konsep pemahaman keilmuan dalam kurikulum Sekolah Islam Terpadu menunjukkan bahwa ini ingin menjadikan anak didiknya memiliki penguasaan keilmuan yang integratif yakni bersatunya penguasaan ilmu ilmu yang bersumber dari ayat-ayat tanziliyah yang menghasilkan sains ketuhanan, ayat-ayat dalam diri manusia yang menghasilkan sains humaniora dan ayat-ayat kauniyah yang menghasilkan sains kealaman.

Sekolah Islam Terpadu dalam aplikasinya memang merupakan sekolah yang menerapkan pendekatan penyelenggaraan dengan memadukan pendidikan umum dan pendidikan agama menjadi suatu jalinan kurikulum. Sekolah Islam Terpadu juga menekankan keterpaduan dalam metode pembelajaran sehingga dapat mengoptilmalkan ranah kognitif, afektif, dan konatif. Sekolah Islam Terpadu juga memadukan pendidikan aqliyah, ruhiyah, dan jasadiyah. Dalam penyelenggaraannya memadukan keterlibatan dan partisipasi aktif lingkungan belajar yaitu sekolah, rumah, dan masyarakat.

\section{Ideologi Pendidikan Islam Terpadu}

Kurikulum Sekolah Islam Terpadu juga merupakan bagian dari ideologi pendidikan yang diadopsi dari Ikhwanul Muslimin. Hal ini tampak dalam sepuluh konsep muwasafat yang menjadi tujuan dalam pendidikan yan diselenggarakan Sekolah Islam Terpadu. Secara spesifik, kurikulum Sekolah Islam Terpadu merupakan kurikulum yang berisi target yang harus dicapai secara berkala dalam beberapa jenjang yang meliputi jenjang muda, madya, dan dewasa (Maksudin, 2010).

Ada sepuluh karakter dari kepribadian Muslim menurut tujuan pendidikan Sekolah Islam Terpadu. Sepuluh karakter kepribadian Muslim ini biasa disebut dengan sepuluh muwasafat. Penjenjangan ini sama dengan konsep muwasafat yang dimiliki oleh Ikhwanul Muslimin, yakni sebagai berikut: 
1. Memiliki akidah yang lurus. Indikator dari karakter ini adalah; mengimani rukun Islam, mematuhi dan tunduk kepada Allah swt., mengikhlaskan amal untuk Allah swt., beriman kepada nikmat dan siksa kubur, mensyukuri nikmat Allah swt. Saat mendapatkannya, menjadikan setan sebagai musuh, tidak bersumpah selain atas nama Allah swt., tidak merasa sial mendengar dan melihat sesuatu, tidak menghadiri perdukunan dan paranormal, tidak meminta tolong kepada jin atau orang yang bekerja sama dengan jin, dan tidak meminta kepada orang yang meninggal.

2. Beribadah yang benar. Karakter ini memiliki indikator sebagai berikut; ihsan dalam thoharoh, ihsan dalam shalat lima waktu, cinta membaca dan menghafal al-Quran, berpuasa fardhu pada bulan ramadhan, ada kecintaan terhadap shalat berjamaah, mendirikan qiyam al-lail minimal sekali dalam sepekan, berpuasa sunnah minimal sekali dalam sepekan, hafal satu juz al-Quran, menutup segala kegiatan dengan istighfar, berdoa pada waktu-waktu mustajab, dan berdzikir dalam segala keadaan.

3. Berakhlak mulia. Karakter ini dicirikan dengan indikator sebagai berikut; memenuhi janji, jujur, berbuat baik kepada orang lain, menjaga kehormatan keluarga, menyayangi yang lebih muda, menghormati yang lebih tua, menjaga pandangan, menjaga rahasia, menutupi aib orang lain, menggunakan barang orang lain dengan seizin pemiliknya, menyebarluaskan salam, menjauhi hal-hal dan perbuatan haram, berteman dengan orang baik, rendah hati dan jauh dari sifat sombong, punya prinsip dan tidak ikut-ikutan, tidak mencaci maki, tidak mengadu domba, dan tidak ghibah dan ngrumpi.

4. Mandiri. Karakter ini memiliki indikator sebagai berikut; menjauhi perbuatan tercela, memenuhi hak orang lain, belajar menabung, menjaga fasilitas umum, menjaga fasilitas dan barang pribadi, dan memenuhi kebutuhan sesuai dengan kemampuan (mandi sendiri, tidur sendiri, dan aktifitas pribadi lainnya).

5. Berwawasan dan berpengetahuan luas. Karakter ini memiliki indikator sebagai berikut; mempunyai kemampuan membaca dan menulis, mempunyai kemampuan mendengarkan dan mengutarakan pendapat, memperhatikan hukum-hukum tilawah, mengetahui sejarah Nabi saw., sungguh-sungguh dalam mengerjakan tugas, menghafal satu juz al-Quran dan Hadis pilihan, dan menyadari adanya gazw al-fikri (perang pemikiran) dengan orang kafir dan penentang Islam. 
6. Berbadan sehat dan kuat. Karakter ini memiliki indikator sebagai berikut; menjaga kebersihan dan ketertiban di rumah, sekolah maupun masyarakat, berolahraga secara teratur, bangun pagi sebelum fajar, hidup sehat, tidak mendekati orang yang merokok, menggunakan narkoba, makan dan minum mengikuti Rasulullah saw., dan menghindari penyakit menular.

7. Bersungguh-sungguh terhadap dirinya. Karakter ini memiliki indikator sebagai berikut; menjauhi segala yang haram, menjauhi tempat-tempat yang haram, dan menjaga kemanan diri.

8. Terampil mengelola segala urusannya. Karakter ini memiliki indikator sebagai berikut; terbiasa menyusun rencana kegiatan, tidak terburu-buru, dan mengisi buku harian.

9. Disiplin waktu. Karakter ini memiliki indikator sebagai berikut; tepat waktu, dan menggunakan waktu untuk hal yang bermanfaat

10. Bermanfaat bagi orang lain. Karakter ini ditandai dengan indikator sebagai berikut; membantu kedua orang tua, senantiasa mendoakan kedua orang tua, membantu yang membutuhkan dengan tenaga, uang dan fikiran, mendiakan teman dan Muslim lainnya, dan menjalankan tugas di rumah, sekolah maupun di masyarakat.

Sepuluh muwasafat ini menjadi ciri khas tujuan pendidikan Sekolah IslamTerpadu yang diadopsi dari sepuluh muwasafat Ikhwanul Muslimin maupun Jamaah Tarbiyah. Dengan melihat sepuluh tujuan pendidikan ini menunjukkan bahwa Sekolah Islam Terpadu benar-benar memiliki tujuan pendidikan sebagaimana yang digariskan oleh Hasan al-Banna. Tujuan pendidikan ini merupakan implikasi dari dimensi akidah dari ideologi pendidikan Sekolah Islam Terpadu. Dimensi akidah ini menuntut setiap aktivitas pendidikan harus bermuara kepada terbentuknya tauhid kepada peserta didik. Konsep ini diintegrasikan dalam proses belajar mengajar yang berlangsung di kelas dan di luar kelas dengan berlandaskan pada kurikulum nasional. Selain itu, pelaksanaan kurikulum dalam proses belajar mengajar juga ditunjang dengan guru yang mampu menjadi teladan bagi siswa. Program ke-IT-an adalah suplemen dari kurikulum yang diterapkan di Sekolah Islam Terpadu. 


\section{Karekteristik Desain Pembelajaran Sekolah Terpadu}

Desain pembelajaran terpadu hendaknya mengakomodasikan prinsip-prinsip belajar yang dirumuskan oleh UNESCO yakni :

a) Belajar untuk memahami dan menghargai orang lain, sejarah mereka dan nilainilai agamanya (learning to live tugether)

b) Belajar untuk menguasai secara mendalam dan luas akan bidang ilmu tertentu (learning to know)

c) Belajar untuk mengaplikasikan ilmu, bekerjasama dalam ilmu, belajar memecahkan masalah dalam berbagai situasi (learning to do )

d) Belajar untuk dapat mandiri, menjadi orang yang bertanggung jawab untuk mewujudkan tujuan berasama (learning to be ) (Sanjaya, 2007).

Proses pembelajaran pendidikan terpadu di sekolah dilaksanakan dengan memperhatikan asas-asas psikologi perkembangan. Semua aktivitas belajar berjalan atas dasar pencapaian tugas-tugas perkembangan dan prinsip-prinsip belajar yang meliputi hal-hal yang terkait dengan kerja kognitif, perbedaan individual, motivasi, bakat, dan kecendrungan, serta tata hubungan antara individu. Tujuan akhir pendidikan terpadu untuk mewujudkan dan merealisasikan penghambaan yang menyeluruh dan total kepada Allah kehidupan manusia baik secara individu maupun sosial.

\section{E. Konsep Pendidikan Islam Terpadu}

\section{Kurikulum}

Ada lima asas hendaknya dijadikan pegangan dalam pengembangan kurikukum pendidikan terpadu, yakni:

a) Asas jelas dan benar, kurikulum pendidikan terpadu harus memiliki rumusan dan perincian tujuan pendidikan yang jelas, yang tertuang dalam silabus, RPP, tertuang dalam buku pegangan siswa, guru maupun orang tua, ia mudah difahami dan dimengerti oleh orang-orang yang menggunakanya.

b) Tertib dan kontinu. Kurikulum sekolah pendidikan terpadu dalam mengajarkan pokok bahasan kepada anak didik harus secara berurutan dan secara berkelanjutan. Artinya setiap pokok bahasan disampaikan berjenjang dan berkelanjutan dalam suatu susunan yang tertib, sesuai dengan tingkat usia dan kematangan psikologis, tidak ada materi yang terputus atau lompat-lompat dalam urutan yang kacau 
c) Efektif dan efisien. Kurikulum pada sekolah terpadu dirancang dengan mempertimbangkan prinsip tepat waktu dan tepat guna.

d) Seimbang dan profesional. Sekolah terpadu memperhatikan keseimbangan antar roh dan akal serta jasad. Program pengajaran dikemas supaya menjangkau dan memenuhi kebutuhan roh, akal, dan jasad tersebut.

e) Integratif dan menyeluruh. Sekolah terpadu berupaya mengintegrasikan segala aspek yang akan menunjang pencapaian tujuan itu sendiri, dan memberikan berbagai kemampuan yang lengkap dan menyeluruh kepada siswa. Keterpaduan ini meliputi:

1. Nilai dan pesan, dalam arti, bahwa sudut pendidikan selalu dilihat dan dikemas berdasarkan agama Islam. Pelajaran umum (seperti: IPA, IPS, dan keterampilan) disampaikan dalam bingkai nilai-nilai Islam;

2. Jangkauan Pendidikan, setiap kegiatan pengajaran harus mengoptimalkan sisi pengetahuan, sikap dan keterampilan;

3. Penyelenggaraan Pendidikan, dalam penyelenggaraan pendidikan harus melibatkan orang tua dan masyarakat;

4. Memberikan kemampuan dasar kepada peserta didik berupa pengetahuan, kemampuan, keterampilan, serta sikap;

5. Mengintegrasikan kemampuan, keterampilan, dan sikap yang Islami kepada peserta didik sehingga dapat tumbuh dan berkembang potensi fitrahnya;

6. Membentuk peserta didik menjadi manusia kepribadian yang saleh dan salehah.

(Wahab, 2012) mengemukakan bahwa pelaksanaan kurikulum dilakukan dengan cara:

a) Kurikulum nasional yang diwarnai dengan nilai-nilai Islam melalui penambahan bidang studi keIslaman baik secara terpisah maupun terintegrasi;

b) Desain kurikulum berorientasi pada kebutuhan peserta didik, lingkungan, dan perkembangan IPTEK;

c) Implementasi kurikulum lebih mengedepankan intgrasi secara fungsional dan kreatif antara aspek kognitif, afektif, dan psikomotorik.

\section{Peserta didik}

a) Memiliki Aqidah yang benar

b) Beribadah secara benar

c) Berakhlak mulia 
d) Cinta dan terampil membaca Al Quran

e) Berakal budi yang cerdas

f) Berbadan sehat dan kuat

g) Dekat dan cinta dengan Al Qur'an

h) Bertindak kreatif : terampil, mandiri dan bertanggung jawab

i) Bersikap positif : santun, toleran, jujur, berani, disiplin,rajin, cinta kasih sesama

\section{Pendidik Dan Tenaga Kependidikan}

a) Memiliki Kualifikasi minimal

b) Memiliki kompetensi sesuai dengan tugasnya

c) Memiliki pemahaman agama dan amaliah yang baik dalam kehidupan seharihari

d) Memiliki keberanian

e) Menunjukan kecintaan bekerja dengan anak

f) Memiliki hubungan yang baik dan harmoni dengan orang tua dan wali murid

g) Melandasi diri dengan keikhlasan akan setiap perilaku profesionalnya.

\section{Metode Pembelajaran}

a) Dialog, Diskusi, dan curah pendapat

b) Metode belajar sinektik (kreatif)

c) Belajar berbantuan komputer yang terkendali dan terarah

d) Belajar sambil berbuat dan

e) Visitasi.

\section{Sarana dan Prasarana}

a) Modifikasi buku teks yang bernuansa Islam

b) Buku refrensi, terutama ensikopedi Islam, al-qur'an tafsir, dan kumpulan hadits

c) Mushalla dan Masjid

d) Laboratarium dan kebun praktek

e) Lingkungan yang kondusif

f) Ahli dalam berbagai bidang.

\section{Evaluasi}

a) Mencakup seluruh aspek kognitif, afektif dan psikomotorik

b) Bersifat edukatif

c) Berlangsung terus menerus 
d) Berorientasi pada individu

\section{Kepemimpinan Kepala Sekolah}

a) Memiliki pemahaman agama yang baik dan berkepribadian terpuji

b) Menunjukan keteladanan

c) Memiliki commen visioner

d) Berwawasan luas dan visioner

e) Bersifat kolegal

f) Memiliki keberanian

g) Memiliki keterampilan leadership

h) Memiliki network yang produktif

i) Memiliki hubungan harmoni dengan para stakeholder

\section{Iklim Sekolah}

a) Kepala Sekolah, guru dan staf mempunyai komitmen tinggi dalam mewujudkan visi dan menjalankan misi sekolah.

b) Kepedulian Kepala Sekolah terhadap kualitas pembelajaran tinggi.

c) Kepala Sekolah memberi tugas kepada guru yang sesuai dengan kewenangan dan kualifikasinya.

d) Kepala Sekolah memonitor pekerjaan yang dilaksanakan oleh guru dan staf.

e) Kebijakan-kebijakan sekolah selalu mengarah kepada peningkatan hasil pendidikan.

f) Guru dan staf menunjukkan komitmen tinggi dalam bekerja.

g) Sekolah mempunyai sistem penghargaan kepada guru, staf dan siswa.

h) Iklim sekolah mendorong guru bekerja profesional

i) Kepala Sekolah, guru dan staf menunjukkan disiplin tinggi.

j) Kepala Sekolah mudah dihubungi guru, staf dan siswa.

k) Kepala Sekolah bersikap responsif kepada guru, staf, siswa, orangtua dan masyarakat.

1) Budaya sekolah mendorong Kepala Sekolah, Guru dan Staf mengembangkan diri.

m) Kondisi lingkungan sekolah rapi, bersih, aman dan terpelihara dengan baik

n) Siswa memiliki disiplin yang tinggi dalam menjalankan tugas dengan baik. 
o) Sekolah membudayakan nilai-nilai demokratis, keagamaan dan keterbukaan.

p) Sekolah membiasakan guru,staf dan siswa untuk berperilaku sesuai ajaran agama

\section{Pendanaan Sekolah}

a) Pendidikan Islam terpadu lebih didasarkan pada kepentingan dakwah, daripada kepentingan bisnis

b) Pemerolehan dana pendidikan harus dilakukan dengan cara yang halal

c) Pemegang dana pendidikan hendaknya benar-benar amanah

d) Penggunaan dana hendaknya lebih banyak diorientasikan untuk kepentingan peningkatan mutu pendidikan

e) Penggunaan dana hendaknya dilakukan selektif dan seefisien mungkin

f) Kesejahteraan personil perlu diusahakan secara optimal dan berdasarkan merit sistem sebagai bagian yang tak terpisahkan dari upaya membangun institusi yang kuat

\section{Pengawasan dan Akuntabilitas}

a) Audit finansial dan kinerja (akademik) dilakukan secara internal dan eksternal

b) Audit dilakukan secara periodik baik sesuai dengan kebutuhan

c) Audit dilakukan oleh orang-orang yang kompeten

d) Pengawasan dilakukan untuk kepentingan pembinaan, bukan untuk pemberian hukuman

e) Pengawasan diorientasikan perbaikan personal dan institusional

Aktivitas audit dan pengawasan lebih dilandasi oleh tanggung jawab kepada Allah SWT.

\section{F. Analisis Sejarah Sosial Munculnya Sekolah Islam Terpadu}

Selama ini praktek pendidikan Islam masih diwarnai praktik dikotomi antara pendidikan agama dangan pendidikan umum. Praktek dikotomi ini telah mengakar dalam sejarah panjang yang dampaknya telah menciptakan munculnya peradaban yang kurang mencerminkan keseimbangan antar dimensi spritualistik dan materialistik dalam kehidupan negara-negara Islam dan untuk mencegah timbulnya kesenjangan dimensi teoritis dan dimensi praktis sekaligus mencari titik temu antara keduanya muncullah gagasan pendidikan terpadu, sebuah model pendidikan yang didesain dengan segala 
keterpaduan dari berbagai sisi dan aspek pendidikan, yang meliputi visi, misi, kurikulum, pendidik, dan suasana pembelajaran (Zubaedi, 2011).

Model pendidikan terpadu selalu dioreintasikan pada pembentukan karekter anak yang utuh baik dari aspek kognitif, afektif, maupun psikomotoriknya. Aspek kognitif anak didik dituntut untuk memiliki wawasan yang luas baik dalam ilmu-ilmu agama maupun ilmu-ilmu umum. Pada aspek afektif anak dituntut memiliki akidah yang benar, bersikap positif, misalnya santun, jujur, berani dan disiplin. Aspek Psikomotorik anak terbiasa mencintai membaca dan menghafal al-Qur'an maupun Hadits, mampu melaksanakan ibadah dengan benar, bertindak trampil dan kreatif.

Sejalan dengan visi, misi dan tujuan sekolah Islam terpadu, sekolah terpadu dirancang dengan sistem terpadu yang memungkinkan siswa mengembangkan potensi dasarnya secara terpadu, terus menerus dan berkesinambungan. Lingkungan pendidikan dirancang sebagai masyarakat belajar, sehingga siswa berintraksi secara langsung dengan masyarakat, guru berperan sebagai pendidik bukan pengajar, guru harus memahami perkembangan siswa, dan guru menjadi sumber keteladanan yang nyata bagi siswa.

Pendidikan terpadu harus menawarkan nilai lebih dari pendidikan lainnya, sehingga siswa mendapatkan pendidikan umum yang penuh dengan nuansa keIslaman, siswa dapat pendidikan agama Islam secara aplikatif dan teoritis, siswa mendapatakan bimbingan ibadah praktis.

\section{SIMPULAN DAN SARAN}

Berdasarkan penjabaran di atas dapat disimpulkan bahwa sekolah Islam terpadu merupakan alternatif yang baik untuk mencetak anak didik yang cerdas secara akal dan juga hati. Orang tua yang khawatir akan kondisi masa depan akhlak putra-putrinya yang dalam hal ini dapat menentukan kondisi bangsa di masa depan dapat mulai untuk beralih sudut pandang mengenai pendidikan yang terbaik untuk buah hatinya.

Melihat respon yang cukup baik dari masyarakat dan juga banyaknya bermunculan sekolah Islam terpadu, agaknya pemerintah juga perlu memberikan perhatiannya pada lembaga ini. Akan lebih baik lagi jika beberapa model pengajaran sekolah Islam terpadu juga diterapkan pada pengajaran mata pelajaran di sekolah umum. 


\section{DAFTAR PUSAKA}

Abdalla, A. (2006). Improving the Quality of Islamic Education in Developing Countries: Innovative Approaches. Washington: Creative Assocites International.

Azhari, M., \& Saleh, A. M. (1989). Islam Indonesia Menatap Masa Depan. Jakarta: P3M.

Fathoni, M. K. (2005). Pendidikan Islam dan Pendidikan Nasional. Jakarta: Departemen Agama RI.

Fitri, H. A., \& Hatta, M. (2013). Madrasah Sebagai Lembaga Pendidikan Islam Dalam Ketahanan Nasional Ipoleksosbudhankam Untuk Mewujudkan Kehidupan Berbangsa Dan Bernegara. Jurnal Ilmiah WIDYA.

Frimayanti, A. I. (2015). Latar Belakang Sosial Berdirinya Lembaga Pendidikan Islam Terpadu Di Indonesia. Al-Tadzkiyyah, 6(1), 27-45.

Hayati, F. (2011). Pesantren sebagai Alternatif Model Lembaga Pendidikan Kader Bangsa. MIMBAR, XXVII(2), 157-163.

Hisyam, U. (2012). Sepanjang Jalan Dakwah Tifatul Sembiring. Jakarta: PT Dharmapena Citra Media.

Kartanegara, M. (2005). Integritas Ilmu. Jakarta: Mizan.

Khadijah, I. (2015). Manajemen Mutu Terpadu (TQM) Pada Lembaga Pendidikan Islam. AL-IDARAH, 5(1), 58-75.

Kurnaengsih. (2015). Konsep Sekolah Islam Terpadu (Kajian Pengembangan Lembaga Pendidikan Islam di Indonesia). Jurnal Risaalah, 1(1), 78-84.

Maksudin. (2010). Pendidikan Islam Alternatif, Membangun Karakter Melalui Sistem Boarding School. Yogyakarta: UNY Press.

Muhaimin, Suti'ah, \& L.P, S. (2009). Manajemen Pendidikan"Aplikasinya dalam Penyusunan Rencana Pengembangan Sekolah/Madrasah. Jakarta: Prenada Media Group.

Qodir, Z. (2009). Gerakan Sosial Islam: Manifesto Kaum Beriman. Yogyakarta: Pustaka Pelajar.

Rifa'i, A. A. (2012). Urgensi Berfikir Strategis Dalam Pengembangan Lembaga Pendidikan Islam Di Indonesia. AKADEMIKA, 17(2), 1-12.

Sada, H. J. (2016). Manusia Dalam Perspsektif Agama Islam. Al-Tadzkiyyah: Jurnal Pendidikan Islam, 7(1), 129-142.

Sanjaya, W. (2007). Strategi Pembelajaran Berorientasi Standar Proses Pendidikan. Jakarta: Kencana Media Group.

Steenbrink, K. A. (1986). Pesantren, Madrasah, Sekolah. Jakarta: Colombia University Press. 
Sulhan, A. (2015). Implementasi Manajemen Mutu Terpadu Lembaga Pendidikan Islam: Sebuah Alternatif Solusi Filsafat. El-HiKMAH, 9(2), 1-22.

Wahab, R. (2012). Desain Pendidikan Terpadu. Jakarta: UNY.

Wijaya, M. U. (1987). Pendidikan Islam dalam Peradapan Industrial. Yogyakarta: Aditia Media.

Zubaedi. (2011). Desain Pendidikan Karakter Konsepsi dan Aplikasi Dalam Lembaga Pendidikan. Jakarta: Perdana Media Group.

Zuhdi, A. (2012). Madrasah Sebagai Tipologi Lembaga Pendidikan Islam (Kajian Tentang Berbagai Model Madrasah Unggulan). Madrasah, 5(1), 1-8. 